\title{
Gametogenic cycle and reproductive effort of the tropical blacklip pearl oyster, Pinctada margaritifera (Bivalvia: Pteriidae), cultivated in Takapoto atoll (French Polynesia)
}

\author{
Stéphane Pouvreau ${ }^{(\mathrm{a}, \mathrm{b} *)}$, Aline Gangnery ${ }^{(\mathrm{c})}$, Jérôme Tiapari ${ }^{(\mathrm{b})}$, Franck Lagarde ${ }^{(\mathrm{b})}$, \\ Matthieu Garnier ${ }^{(d)}$, Alain Bodoy ${ }^{(a)}$ \\ (a) Crema (Ifremer-CNRS), BP 5, 17137 L'Houmeau, France \\ (b) Ifremer Cop, BP 7004, Taravao Tahiti, French Polynesia \\ (c) Ifremer-Palavas, Chemin de Maguelone, 34250 Palavas-Les-Flots, France \\ (d) CNRS-Station Biologique, Place G. Teissier, BP 74, 29682 Roscoff, France
}

Received February 25, 1999; accepted December 2, 1999

\begin{abstract}
The gametogenic cycle and the reproductive effort of the blacklip pearl oyster, Pinctada margaritifera, cultivated in Takapoto lagoon were studied for a 1-year period (March 1997-April 1998) by bimonthly observations of gonadal sections, dry tissue weights and gonadal index in a population of pearl oyster composed of three age-groups. Pearl oysters attained sexual maturity in the end of their first year (height $\approx 40 \mathrm{~mm}$ ), implying that $P$. margaritifera is a late-maturing species in comparison with other Pteriidae. This species was also confirmed to be a marked protandrous successive hermaphrodite in culture, with $100 \%$ of males at first maturity and $75 \%$ in older pearl oyster (height $>120 \mathrm{~mm}$ ). The general pattern of gametogenic activity, fairly synchronous in both sexes, was comparable with that of other tropical bivalves: reproduction occurs continuously throughout the year with a maximal activity during the warm season (November-May). No resting period was observed. Quantitative growth data showed that $P$. margaritifera exhibits an annual synchronised polymodal spawning pattern, with two spawning peaks in age-group I (height $\approx 70 \mathrm{~mm}$ ) and five in age-groups II (height $\approx 100 \mathrm{~mm}$ ) and III (height $\approx 120 \mathrm{~mm}$ ). Spawning was sometimes incomplete, nevertheless a clear relationship between gamete production $\left(\mathrm{P}_{\mathrm{R}}, \mathrm{g}\right)$ and size $($ height $\mathrm{H}, \mathrm{mm})$ was obtained: $\mathrm{P}_{\mathrm{R}}=$ $5.26 \times 10^{-7} \mathrm{H}^{2.91}\left(\mathrm{R}^{2}=0.99, P<0.05\right)$. Estimation of $\mathrm{P}_{\mathrm{R}}$ was used to calculate the annual reproductive effort in $P$. margaritifera. Reproductive effort $(\%)$ was similar to those calculated for temperate species and showed a progressive increase with the age of pearl oyster, from $7 \%$ in age-group I to $38 \%$ in age-group III. This study showed that, in a fairly stable tropical environment such as the Takapoto lagoon, $P$. margaritifera is a multiple spawner, which uses an opportunistic reproductive strategy, allowing investment, all year around, of any surplus energy into gamete production. Surplus energy is ensured by the high pumping rates developed by this non-symbiotic bivalve to succeed in low seston conditions. (C) 2000 Ifremer/Cnrs/Inra/Ird/Cemagref/Éditions scientifiques et médicales Elsevier SAS
\end{abstract}

Blacklip pearl oyster / gametogenesis / tropical aquaculture / reproductive cycle / reproductive effort / French Polynesia

Résumé - Cycle et effort de reproduction de l'huître perlière, Pinctada margaritifera (Bivalves: Ptériidés), en élevage dans l'atoll de Takapoto (Polynésie Française). Le cycle et l'effort de reproduction de l'huître perlière à lèvres noires, Pinctada margaritifera, cultivée dans le lagon de Takapoto, ont été étudiés sur une période annuelle (de mars 1997 à avril 1998), par un suivi bimensuel des stades de maturation et des indices gonadiques, sur une population en élevage composée de trois groupes d'âge ( 1,2 et 3 ans). Cette étude a confirmé que $P$. margaritifera est une espèce qui se reproduit tardivement par rapport aux autres Ptériidés (elle atteint sa maturité sexuelle à la fin de sa première année, pour une hauteur approximative de $40 \mathrm{~mm}$ ). Par ailleurs, elle présente, en élevage, une protandrie marquée (100\% de mâles à première maturité, $75 \%$ pour des huîtres âgées de trois ans). Le schéma général de sa gamétogenèse, relativement synchrone dans les deux sexes, est comparable à celui des autres bivalves tropicaux : la reproduction est quasiment continue (aucune période de repos sexuel) avec une activité accrue en saison chaude (de novembre à mai). L'analyse des variations du poids de la gonade suggère l'existence de deux pics d'émission de gamètes chez les huîtres de un an et cinq pics chez les huîtres de 2 et 3 ans (cycle de reproduction de type polymodal). Bien que ces émissions de gamètes soient parfois incomplètes, une relation entre la production de gamètes $\left(\mathrm{P}_{\mathrm{R}}\right.$, en $\left.\mathrm{g}\right)$ et la taille de l'huître perlière (hauteur, $\mathrm{H}$, en $\mathrm{mm}$ ) a été établie : $\mathrm{P}_{\mathrm{R}}=5,26 \times 10^{-7} \mathrm{H}^{2,91}\left(\mathrm{R}^{2}=0,99, p<0,05\right)$. Ces résultats ont permis de calculer l'effort de reproduction de $P$. margaritifera à Takapoto et sur un bilan annuel : il augmente avec l'âge de l'huître perlière de $7 \%$ pour le groupe d'âge I à $38 \%$ pour le groupe d'âge III. Ces valeurs annuelles sont similaires à celles calculées chez les bivalves de milieux tempérés. Cette étude a donc montré que, dans un environnement tropical assez stable tel que celui du lagon de Takapoto, P. margaritifera présente une reproduction continue, avec 
plusieurs pics d'émission de gamètes par an. Cette stratégie « opportuniste » permet l'investissement, de tout surplus d'énergie en production de gamètes, tout au long de l'année. Malgré la faible concentration du milieu en nourriture, ces surplus d'énergie sont assurés par les fortes capacités de filtration développées par cette espèce tropicale non-symbiotique. (C) 2000 Ifremer/Cnrs/Inra/Ird/Cemagref/Éditions scientifiques et médicales Elsevier SAS

Huître perlière / gamétogenèse / aquaculture tropicale / cycle de reproduction / effort de reproduction / Polynésie française

\section{INTRODUCTION}

The blacklip pearl oyster, Pinctada margaritifera (Linnaeus, 1758) var cumingi (Reeve), occurs throughout the coral areas of the Indo-Pacific, but is really abundant in atolls of French Polynesia. Apart from for the goldlip pearl oyster, P. maxima (Jameson), which inhabits the north Australian region, P. margaritifera grows to a much larger size than the other species of the genus and is able to produce larger pearls. Today, black pearl aquaculture plays a major economic role in French Polynesia; the annual production is six metric tons of pearls (\$US 175 million). After the large scale mortality which decimated cultivated pearl oysters from several atolls in 1985, French Polynesia decided to set up a general research programme on the pearl oyster, the so-called PGRN. The main objective of PGRN was to gain new knowledge on the ecology of $P$. margaritifera in lagoon environment with the aim of modelling the carrying capacity of pearl farming sites. In that respect, a first step was to build a physiological model which explained growth and reproduction of the pearl oyster according to its environment. These kinds of models have already been achieved for temperate species $[2,3,48$, $55,58,71]$ but nothing was available for tropical bivalves. In order to build such a model for $P$. margaritifera, the entire feeding process was studied, using field experiments $[44,45]$. Once the model was built, growth and reproduction data were required to test the adequacy and reliability of the model. In this respect, the reproductive biology of $P$. margaritifera was investigated in Takapoto atoll, providing, at the same time, useful information for the pearl industry (resource management, development of hatchery technique, selective breeding programme, etc.).

As a general rule, most species of bivalves show flexibility in their reproductive cycle according to environmental variability [30, 31]. Reproduction of bivalves was mainly studied in temperate species (e.g. for Pectinidae [1, 7, 13, 14, 32, 36, 37, 42, 53, 64]; for Mytilidae [4, 43, 51, 59, 73]; for Ostreidae [9, 12, 25, 29, 61]; for other orders [11, 20, 21, 23, 40, 49, 52, 77]) which generally exhibit a seasonal reproductive strategy, organised into four steps: storage, gametogenesis, spawning, and inactivity. However, in some species, storage and gametogenesis may tend to overlap temporally, which led Bayne [4] to divide the bivalve gametogenic pattern from temperate areas into two groups: 1) 'conservative' species, with gametoge- nesis occurring in autumn/winter by using energy stores previously accumulated during the summer; this strategy implies that the peak of gamete production takes place during less favourable period; 2) 'opportunistic' species, with gametogenesis delayed until spring/summer, when food is sufficient; in this case, the peak period of gamete production coincides with maximum food availability, winter corresponding to a resting period.

More recently, species inhabiting environments with low seasonal trends (tropical but also polar or deep sea areas) have been studied $[8,15,16,22,24,26-28,60$, 75] and their reproductive strategy shows marked differences: the main specificity is that breeding is generally continuous $[31,56]$.

Studies on gametogenesis and breeding cycles of pearl oysters are available: 1) in Australian waters for Pinctada fucata martensii [70], for P. maxima [54], for $P$. albina [66-68] and for P. margaritifera [69]; 2) in Japanese waters for P. fucata fucata [74]; 3) in Californian waters for $P$. mazatlanica [18]. In French Polynesian waters, reproduction of $P$. margaritifera has been previously investigated [65] but only for ultrastructural aspects of spermatogenesis.

The aim of this study was to complete this preliminary work by examining, on an annual basis, the gametogenic cycle and reproductive output of three age-groups of $P$. margaritifera cultivated in Takapoto lagoon. The results presented here were determined from qualitative histological observations and quantitative gonadal growth data.

\section{MATERIALS AND METHODS}

\subsection{Sampling, biometry and histology}

Reproduction of cultivated pearl oysters was studied in Takapoto lagoon. Takapoto atoll is located in the Tuamotu Island of French Polynesia. This atoll (latitude $14^{\circ} 30^{\prime} \mathrm{S}$ and longitude $145^{\circ} 20^{\prime} \mathrm{W}$ ) is $18.7 \mathrm{~km}$ long and $4.4 \mathrm{~km}$ wide, and presents an area of $81.7 \mathrm{~km}^{2}$. Mean depth of the lagoon is $23 \mathrm{~m}$, with a maximum at $55 \mathrm{~m}$. The volume of water is estimated between $1.3 \mathrm{~km}^{3}$ [62] and $2.3 \mathrm{~km}^{3}$ (Yann Morel, pers. comm.). Exchanges with the ocean are very restricted because of the absence of channels into the coral ring. Homogeneity in the body water is ensured by regular trade winds. Sometimes, calm conditions may occur, 


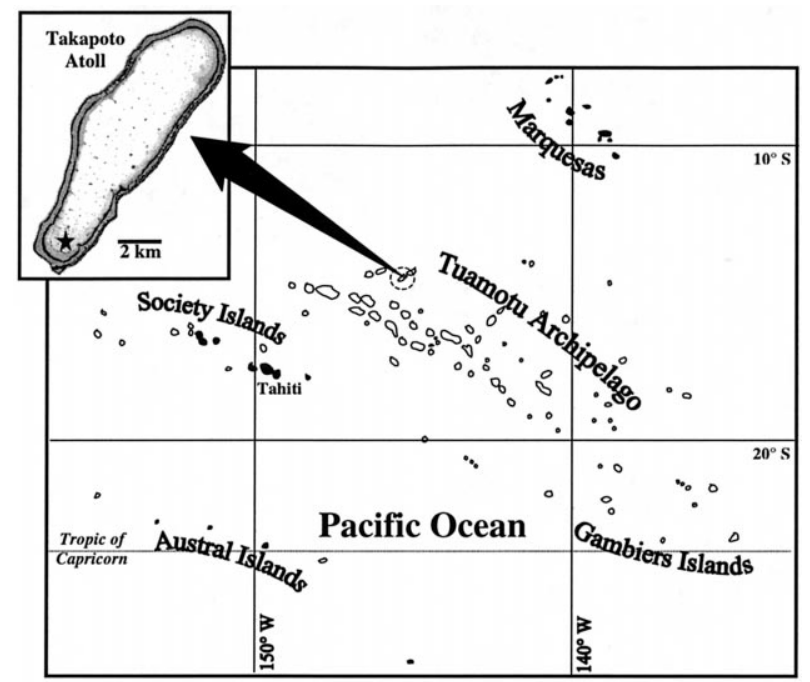

Figure 1. French Polynesia islands and location of the Takapoto atoll. Polynesian islands are in black and atolls in white. Star indicates the location, in Takapoto lagoon, of the cultivated oysters studied in this work.

especially during the warm season (November-April), causing occasional development of stratification.

To study reproduction of $P$. margaritifera for several age-groups, three populations of pearl oysters were cultivated at a single station (station 1) in the SW extremity of Takapoto lagoon (see figure 1). The first cohort was collected in March 1994 (age-group III), the second in March 1995 (age-group II) and the third in March 1996 (age-group I). The age of the three cohorts was estimated based on the March spat fall. Error in estimation was \pm 2 months (uncertainty in time of spat settlement). Farming of these pearl oysters was conducted by the SRM field laboratory. The cultivation technique was very close to that commonly used in commercial farms. Suspended long-lines were immersed at $7 \mathrm{~m}$ deep. Pearl oysters were 'ear hung' on downline at low density $\left(<20\right.$ oysters $\left.\mathrm{m}^{-3}\right)$ except for young oysters which were arranged in lantern nets where density was somewhat higher.

The reproduction cycle was followed for 1 year (from March 1997 to April 1998). A systematic sampling scheme was conducted: every 15 days, 45 individuals were randomly collected by SCUBA in each age-group, cleaned of fouling organisms and sent by aircraft to Ifremer Laboratory on Tahiti island. Then, they were stored under refrigeration at approximately $5{ }^{\circ} \mathrm{C}$ and analysed within $24 \mathrm{~h}$ of collection.

For all specimens $(n=3360)$, shell height (dorsoventral axis, H) was first measured to the nearest millimetre prior to sexing, dissection, weighing and histology. Sex (indeterminate, male, female, hermaphrodite) was then observed. Since males and females of $P$. margaritifera are externally difficult to distinguish, sex was determined by rapid microscopic observation of fresh gonad smears. Dry shell weight (both valves,
$\left.\mathrm{W}_{\text {Shell }}\right)$ was obtained after drying at $60^{\circ} \mathrm{C}$ for $72 \mathrm{~h}$, and total wet tissue weight after 5 min of draining. After flesh dissection, the same operation was conducted, separately, on adductor muscle, on retractor muscle, on (gills + mantle) and on (gonad + digestive gland). Dry weight of each part was obtained after complete freeze-drying. Tissue water content was determined by the difference between wet and dry weights, ash content was obtained on a sub-sample $(n=10)$ every 15 days after ignition in a muffle furnace at $500{ }^{\circ} \mathrm{C}$ for $12 \mathrm{~h}$.

Gonad histology was performed on a sub-sample $(n=15)$ in each age-group. After being dissected, gonadal tissue samples (+ digestive gland) were placed in Bouin-Hollande's fixative for a few days, after which they were preserved in $70 \%$ alcohol. Samples were then dehydrated through a graded series of alcohol, embedded in paraffin, sectioned at 3-4 $\mu \mathrm{m}$ on a rotary microtome, stained with Giemsa colorant and finally mounted on microscope slides. Sections were made from the gonadal area between the proximal end of the gut loop and the base of the foot. The sections were examined with a light microscope, first under low power $(40 \times)$ to scan the entire gonadal area and, then, under high power $(200 \times)$ to assess follicle stages.

\subsection{Qualitative reproductive analysis}

After preliminary examinations of a wide range of slides and preliminary review of the existing bibliography on Pteriidae reproduction, a seven-stage reproductive staging criterion was adapted from the classification cited for P. margaritifera [69], P. maxima [54], P. fucata [74] and P. mazatlanica [18]. Each of these classifications had advantages and disadvantages: Rose et al. [54], Wada et al. [74] and GarciaDominguez et al. [18] studied other species of Pteriidae; Tranter [69] worked on P. margaritifera, but his classification was somewhat complicated (nine stages) and difficult to set routinely. Using the merits of these four studies, a new classification was established for gonadal development of $P$. margaritifera in Polynesian waters (table I). Sometimes, more than one stage occurred simultaneously within an individual. When this occurred, stage criterion decisions were based upon the condition of the majority of the section. A total of 1200 individuals was examined histologically to determine the gametogenic cycle.

\subsection{Quantitative reproductive analysis}

A simple and quantitative indicator of the reproductive state is the gonad index GI $[27,75]$. This index is useful to determine potential spawning period (minimal GI-values). In our study, GI was computed for each individual, by using the following equation:

$$
\mathrm{GI}=\mathrm{W}_{\text {Gonad }} / \mathrm{W}_{\text {Shell }}
$$

where $\mathrm{W}_{\mathrm{Gonad}}$ is the dry tissue weight of gonad + digestive gland and $\mathrm{W}_{\text {Shell }}$ is the dry weight of shell (in 
Table I. Reproductive stages in gonad development of the genus Pinctada. Staging criteria used in this study were adapted from those of previous works $[18,54,69,74]$. This table shows the relationship between the stages used in our study $\left(0,1,2,3,4, R_{\mathrm{P}}, \mathrm{R}_{\mathrm{T}}\right)$ and those used in previous works. For some of them, stages have been regrouped (see the braces).

\begin{tabular}{|c|c|c|c|c|c|}
\hline \multicolumn{4}{|c|}{ Classification used in previous studies } & \multirow{2}{*}{$\begin{array}{l}\text { Classification in this } \\
\text { study }\end{array}$} & \multirow{2}{*}{ Histological criteria } \\
\hline [69] & {$[54]$} & [74] & {$[18]$} & & \\
\hline \multicolumn{6}{|c|}{ Gonad inactivity } \\
\hline i & 0 & - & indifferent stage & 0 & indeterminate or inactive, no evidence of gonadal development \\
\hline \multicolumn{6}{|c|}{ Gonad development } \\
\hline$d_{1}-d_{2}$ & 1 & 1 & & 1 & early gametogenesis, follicles small, gonia numerous \\
\hline $\mathrm{d}_{3}$ & 2 & 2 & $\begin{array}{l}\text { developing } \\
\text { stages }\end{array}$ & 2 & actively developing, but matures gametes are not observed \\
\hline $\mathrm{d}_{4}$ & & 3 & & 3 & near ripe follicles with matures gametes \\
\hline$d_{5}$ & 3 & 4 & ripe stage & 4 & spawning ripe, follicles distended, confluent and entirely filled \\
\hline \multicolumn{6}{|c|}{ Gonad regression } \\
\hline$r_{1}-r_{2}$ & 4 & 5 & $\begin{array}{l}\text { partially } \\
\text { spawned }\end{array}$ & $\mathrm{R}_{\mathrm{P}}$ & partially spawn, partially empty lumen \\
\hline$r_{3}$ & & $6-7$ & spent stage & $\mathrm{R}_{\mathrm{T}}$ & spent, completely empty lumen \\
\hline
\end{tabular}

$\mathrm{i}$, indeterminate; $\mathrm{d}$, development; $\mathrm{r}$, regression; $\mathrm{R}_{\mathrm{P}}$, partial regression; $\mathrm{R}_{\mathrm{T}}$, complete regression.

g). In some works, flesh weight is used in place of shell weight, but the calculation of the gonad index on this basis may create problems since flesh weight is known to vary periodically, with higher amplitude than shell weight. Furthermore, preliminary calculations showed that GI based on shell weight was the best discriminant index concerning reproductive activity.

Gonad index variation was also useful to analyse synchronicity of gametogenesis: if heteroscedasticity is detected between samples, then gametogenesis could be suspected to be asynchronous. To check homogeneity of GI variance between samples, Cochran's C test, within Statgraphic's plus Software, was performed for each age-group and for each sex of pearl oysters. The value of this test increases when homoscedasticity decreases.

Once potential spawning periods were determined and gametogenesis synchronicity was tested, gamete production $\left(\mathrm{P}_{\mathrm{R}}\right)$ was estimated on the basis of the gonad dry weight losses, as follows:

$$
\mathrm{P}_{\mathrm{R}}(\mathrm{t})=\mathrm{W}_{\text {Gonad }}(\mathrm{t}-1)-\mathrm{W}_{\text {Gonad }}(\mathrm{t}+1)
$$

where $\mathrm{W}_{\text {Gonad }}(\mathrm{t}-1)$ and $\mathrm{W}_{\text {Gonad }}(\mathrm{t}+1)$ are the dry tissue weight of gonad + digestive gland just before and just after spawning, respectively.

For a whole year, the total gamete production $\left(\mathrm{P}_{\mathrm{R}}, \mathrm{g}\right)$ was then compared to annual soft tissue production $\left(\mathrm{P}_{\mathrm{G}}, \mathrm{g}\right)$ and annual organic shell production $\left(\mathrm{P}_{\mathrm{S}}, \mathrm{g}\right)$ using two indices, called reproductive effort, $\mathrm{ER}_{1}$ and $\mathrm{ER}_{2}$, expressed in per cent and calculated as follows:

$$
\begin{gathered}
\mathrm{ER}_{1}=100 \times \mathrm{P}_{\mathrm{R}} /\left(\mathrm{P}_{\mathrm{R}}+\mathrm{P}_{\mathrm{G}}\right) \\
\mathrm{ER}_{2}=100 \times \mathrm{P}_{\mathrm{R}} /\left(\mathrm{P}_{\mathrm{R}}+\mathrm{P}_{\mathrm{G}}+\mathrm{P}_{\mathrm{S}}\right)
\end{gathered}
$$

The reproductive effort is known to increase with age, and a logistic model $\left(\mathrm{ER}=\mathrm{ER}_{\infty} /\left[1+\mathrm{a} \cdot \mathrm{e}^{(-\mathrm{kt})}\right]\right)$ was proposed for $P$. margaritifera in Takapoto atoll. This model was fitted by the Marquardt algorithm within Statgraphic's plus Software.

\section{RESULTS}

\subsection{Sexuality}

No indeterminate stage was observed during the study and mature individuals were found in all size classes sampled (figure 2). In this respect, initial sexual maturity size, corresponding to the smallest individuals with mature gonads (stage 4), is presumably below $40 \mathrm{~mm}$.

Samples taken biweekly were combined into monthly values in table II. The month-by-month analysis of this table indicated that the sex-ratio was always significantly different from 1:1 $\left(\chi^{2}\right.$ test, $P<$ 0.05 ) for all samples. More precisely, sex-ratio showed a clear relationship with the size of individuals (figure 2): individuals $<90 \mathrm{~mm}$ were exclusively males and sex-inversion appeared around $90 \mathrm{~mm}$. Above this size, the proportion of females increased progressively

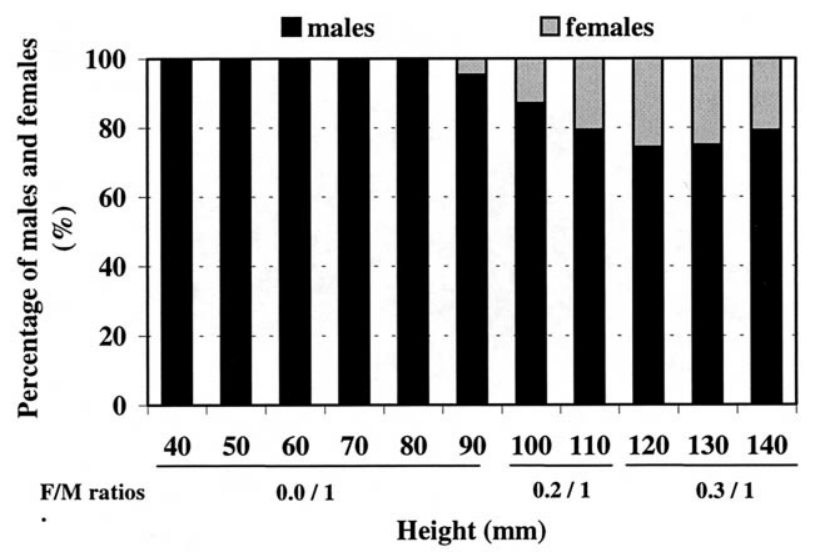

Figure 2. Relative size frequency distributions for P. margaritifera females and males cultivated in Takapoto lagoon. Sex-inversion occurs for specimens $>80 \mathrm{~mm}$. 
Table II. Sex ratios in three age-groups of $P$. margaritifera, from March 1997 to April 1998.

\begin{tabular}{lccc}
\hline & \multicolumn{3}{c}{ F/M ratio } \\
\cline { 2 - 4 } \multicolumn{1}{c}{ Months } & Age-group I & Age-group II & Age-group III \\
\hline March 1997 & $0.0 / 1$ & $0.0 / 1$ & $0.2 / 1$ \\
April 1997 & $0.0 / 1$ & $0.1 / 1$ & $0.2 / 1$ \\
May 1997 & $0.0 / 1$ & $0.1 / 1$ & $0.3 / 1$ \\
June 1997 & $0.0 / 1$ & $0.1 / 1$ & $0.4 / 1$ \\
July 1997 & $0.0 / 1$ & $0.2 / 1$ & $0.2 / 1$ \\
August 1997 & $0.0 / 1$ & $0.1 / 1$ & $0.4 / 1$ \\
September 1997 & $0.0 / 1$ & $0.2 / 1$ & $0.4 / 1$ \\
October 1997 & $0.0 / 1$ & $0.3 / 1$ & $0.3 / 1$ \\
November 1997 & $0.0 / 1$ & $0.3 / 1$ & $0.3 / 1$ \\
December 1997 & $0.0 / 1$ & $0.2 / 1$ & $0.5 / 1$ \\
January 1998 & $0.0 / 1$ & $0.3 / 1$ & $0.6 / 1$ \\
February 1998 & $0.0 / 1$ & $0.3 / 1$ & $0.3 / 1$ \\
March 1998 & $0.0 / 1$ & $0.5 / 1$ & $0.3 / 1$ \\
April 1998 & $0.0 / 1$ & $0.3 / 1$ & $0.5 / 1$ \\
Mean & $0.0 / 1$ & $0.2 / 1$ & $0.3 / 1$ \\
\hline
\end{tabular}

F, females; M, males.

and reached approximately $25 \%$ in oldest individuals. In this respect, $P$. margaritifera in culture systems is a protandric successive hermaphrodite species with a highly dominant male phase. Bisexuality was uncommon: only seven simultaneous hermaphroditic pearl oysters were observed among the 3360 analysed specimens, with no evidence that both gonads were functional.

\subsection{Gametogenic cycle}

The temporal distribution of pearl oysters in various maturity stages during the year is illustrated in figure 3 . From these data, it is apparent that: 1) sexually undifferentiated individuals were never encountered during the course of this study; 2) gametogenic activity was clearly evident throughout the year in all specimens $>1$ year old, without any clearly defined seasonal reproductive cycle; and 3 ) no resting period was apparent.

More precisely, figure 3 showed that ripe (stages 3-4) and partially spawned (stage $\mathrm{R}_{\mathrm{P}}$ ) individuals were observed all through the year with a high percentage, generally above $70 \%$, except at the end of the austral winter (September), where this percentage decreased to approximately $40 \%$. In contrast, developing stages (stages 1-2), found every month, represented generally less than $40 \%$, except at the end of the austral winter (September), where the value was somewhat higher (approximately $60 \%$ ) for both sexes. Figure 3 showed also that no resting period (indeterminate stage) occurred during the gametogenic cycle of $P$. margaritifera in this environment. Total regression stage $\left(R_{T}\right)$ was very scarcely observed during the study period.

The fact that $70 \%$ of the population were in spawning-ripe or in partially spawned stages indicated that reproduction of $P$. margaritifera in Takapoto
Table III. Test for homogeneity in variance of gonadal index (GI). Values on the Cochran's $C$ test showed that variance was homogeneous $(P>0.05)$ in all age-groups independently of the sex or the age of pearl oyster.

\begin{tabular}{lcc}
\hline & Cochran's test & Probability level \\
\hline Age-group I & 0.060 & 0.39 \\
Age-group II & & \\
$\quad$ Males & 0.062 & 0.36 \\
$\quad$ Females & 0.102 & 0.33 \\
Age-group III & & \\
$\quad$ Males & 0.063 & 0.41 \\
$\quad$ Females & 0.138 & 0.05 \\
\hline
\end{tabular}

lagoon is fairly synchronous. To test this global synchronicity in reproductive activity, homogeneity in gonad index (GI) variances between sampling was checked by using Cochran's C test. Asynchronicity in reproductive activity was rejected since the Cochran's $\mathrm{C}$ test values showed that variance was homogeneous $(P>0.05)$ in all age-groups, independent of the sex or the age of pearl oysters (table III).

To quantify in a more precise way the reproductive activity, variations in dry weight of gonad $\left(\mathrm{W}_{\mathrm{Gonad}}\right)$ and in gonad index (GI) were analysed. Since theses variations were not significantly different between males and females, data were pooled. Concerning $\mathrm{W}_{\text {Gonad }}$, figure 4 showed several monthly cycles, especially in age-groups II and III, underlying rapid reproductive cycle. For example, five significant decreases were observed in $\mathrm{W}_{\text {Gonad }}$ for age-group III pearl oysters. Three of them represented approximately $30 \%$ of $\mathrm{W}_{\text {Gonad }}$ : in May $1997(-0.58 \mathrm{~g} \pm 0.19$ $\mathrm{CI})$, in January $1998(-0.70 \mathrm{~g} \pm 0.23 \mathrm{CI})$ and in March $1998(-0.61 \mathrm{~g} \pm 0.29 \mathrm{CI})$, and two of them were lower (approximately $20 \%$ ): in September $1997(-0.39 \mathrm{~g} \pm$ $0.29 \mathrm{CI})$ and in November 1997 (-0.36 g $\pm 0.36 \mathrm{CI})$. These variations were presumably due to gamete emissions or digestive gland resorption.

To determine the origin of these losses, GI monthly variations were analysed since GI and maturity stages were clearly related as described by figure 5: GI increased progressively with the development of maturity to reach a maximal value $(1.02 \pm 0.02 \mathrm{CI})$ in ripe (stage 4) pearl oysters, and decreased afterwards with regression stages to a minimal value of $0.84( \pm 0.08$ CI) for complete regression stage (high CI, scarcely observed). Concerning these variations, figure 6 shows a great irregularity, especially in age-groups II and III. Taking into account the relationship between GI and maturity stages, increases in GI should indicate developing gametogenesis, whereas obvious GI decreases should indicate principal spawning. In this respect, if some small irregularities in curves were not significant, and were presumably due to sampling variability and/or minor spawning or gamete resorption, five major and statistically significant variations, supporting those observed in gonad weight, could be determined in age-groups II and III, and two in age-group I. For example, in age-group III, during the month of 

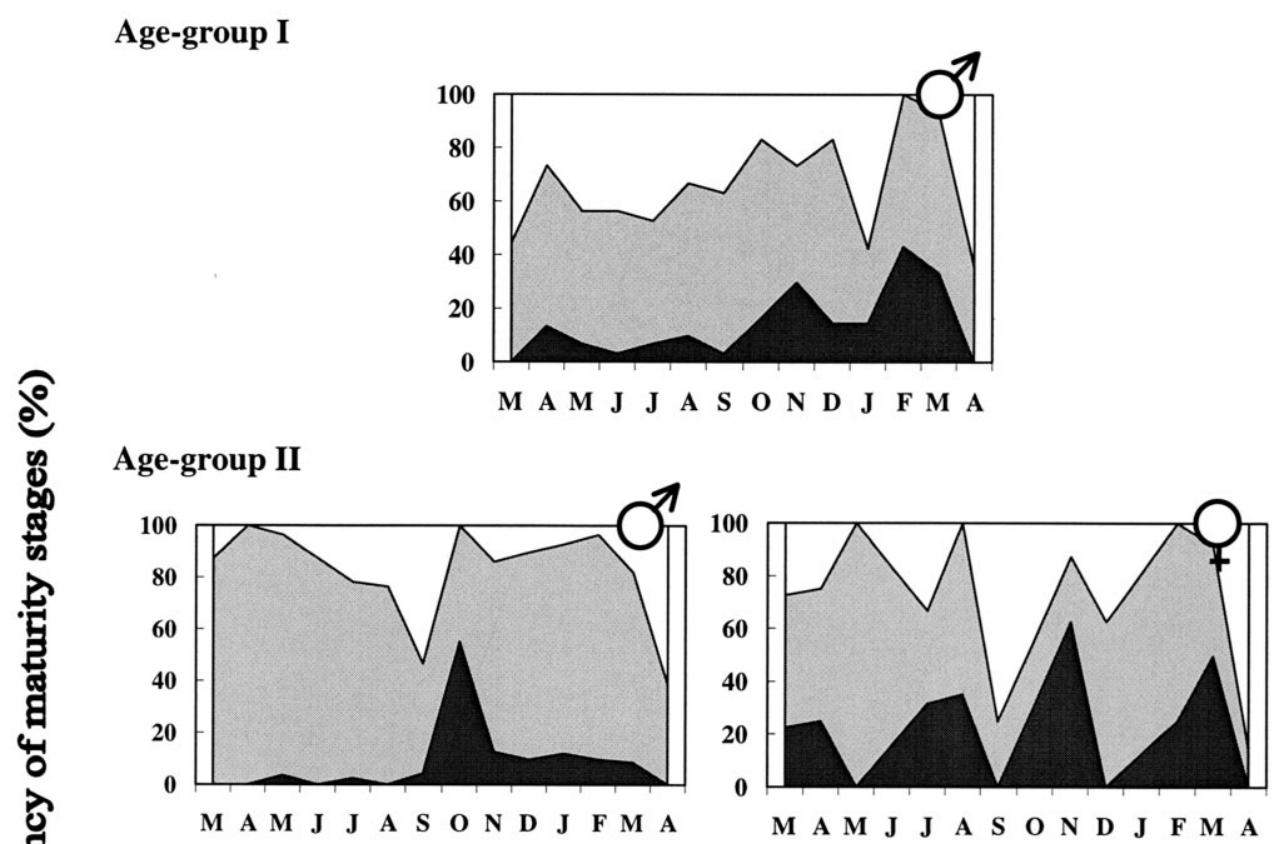

\section{Age-group III}
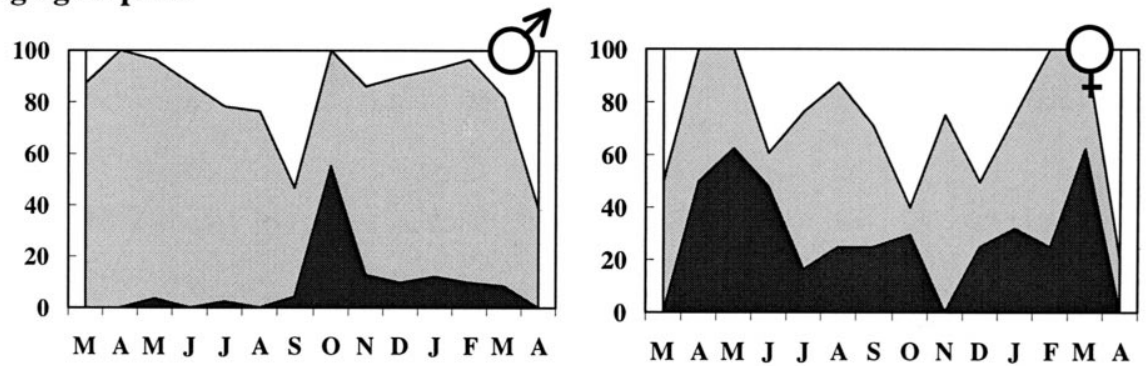

Figure 3. P. margaritifera. Monthly evolution of gonadal development stage frequency in males and females, for three age-groups. $\square$, early gametogenesis (stages 1-2); $\square$, spawning-ripe (stages 3-4); $\mathbf{\square}$, partially spawned to spent (regression stages).

April 1997, the gonadal index increased from 0.9 to a maximal value of 1.2 in May 1997, and then decreased to a minimum of 0.8 in early June 1997 . The decrease was statistically significant (Student's $t$-test, $P<0.05$ ) and corresponded to a major spawning event. In the following months, GI showed similar significant variations on four occasions (see arrows in figure 6). At least five major spawning events were observed in age-groups II and III, and two in age-group I. The particular months were: May 1997, September 1997, November 1997, January 1998 and March 1998.

\subsection{Reproductive output}

Losses in gonad weight corresponding to each of the five spawning periods previously described were calculated for each age-group (see table IV). Values varied from 0.09 to $0.15 \mathrm{~g}$ in age-group I, from 0.16 to $0.55 \mathrm{~g}$ in age-group II and from 0.36 to $0.70 \mathrm{~g}$ in age-group III. Theses losses corresponded approximately to a decline between 4 and $11 \%$ of the total dry tissue weight. A clear relationship with pearl oyster height $(\mathrm{H}, \mathrm{mm})$ was demonstrated (figure 7): $\mathrm{P}_{\mathrm{R}}$ values increased with $\mathrm{H}$ by following the equation: $\mathrm{P}_{\mathrm{R}}(\mathrm{g})=$ $5.26 \times 10^{-7} \mathrm{H}^{2.91}\left(\mathrm{R}^{2}=0.99, P<0.05\right)$.

Reproductive effort (ER, \%), i.e. the fraction of total growth allocated to reproduction, was calculated ( $t a$ ble $V$ ) on the basis of the annual production values by using two different formulae $\left(\mathrm{ER}_{1}\right.$ and $\left.\mathrm{ER}_{2}\right)$. $\mathrm{ER}_{1}$ (which does not take into account shell production) increased with the age of pearl oyster from 16.5 to

Table IV. Mean gametes losses $\left(\mathrm{P}_{\mathrm{R}}, \mathrm{g}\right) \pm \mathrm{CI}$ (in brackets) in each age-group for the major spawning periods.

\begin{tabular}{lccc}
\hline & \multicolumn{3}{c}{ Gamete production $\left(\mathrm{P}_{\mathrm{R}}, \mathrm{g}\right)$} \\
\cline { 2 - 4 } & Age-group I & Age-group II & Age-group III \\
\hline May 1997 & & $0.16(0.14)$ & $0.58(0.19)$ \\
September 1997 & $0.09(0.04)$ & $0.43(0.21)$ & $0.39(0.29)$ \\
November 1997 & & $0.54(0.23)$ & $0.36(0.36)$ \\
January 1998 & $0.15(0.05)$ & $0.42(0.20)$ & $0.70(0.23)$ \\
March 1998 & & $0.55(0.27)$ & $0.61(0.29)$ \\
\hline
\end{tabular}

Aquat. Living Resour. 13 (1) (2000) 


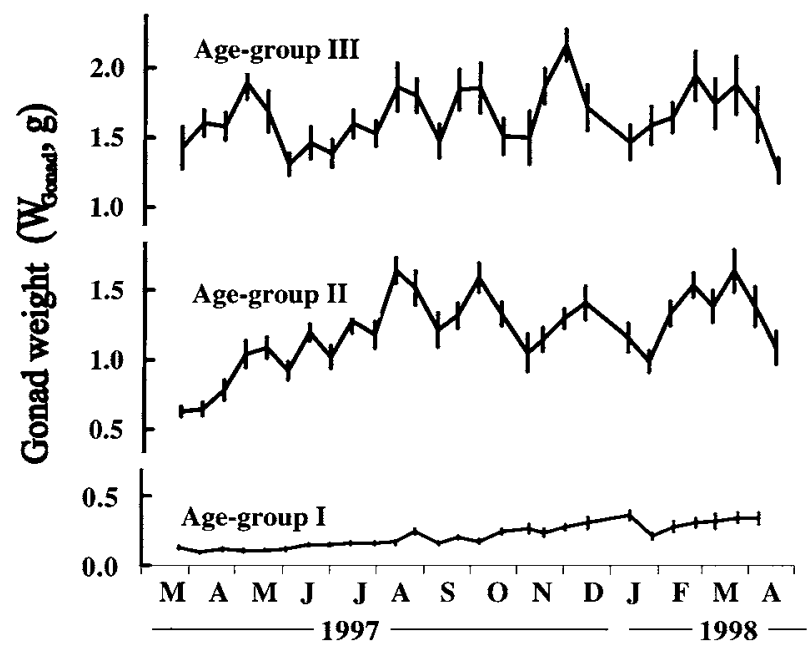

Figure 4. P. margaritifera: monthly evolution of dry weight of gonad (+ digestive gland), $\mathrm{W}_{\mathrm{Gonad}}$, for three age-groups. Preliminary insights into the data showed that $\mathrm{W}_{\mathrm{Gonad}}$ evolution of males and females followed the same pattern, so that all the data were pooled. Vertical bars represent the $95 \%$ confidence intervals.

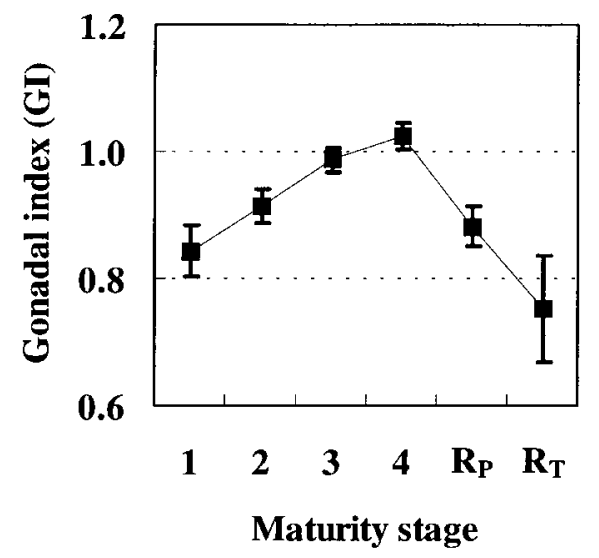

Figure 5. Relationship between GI gonad index and gametogenic stage computed for all age-groups. Vertical bars represent the $95 \%$ confidence intervals.

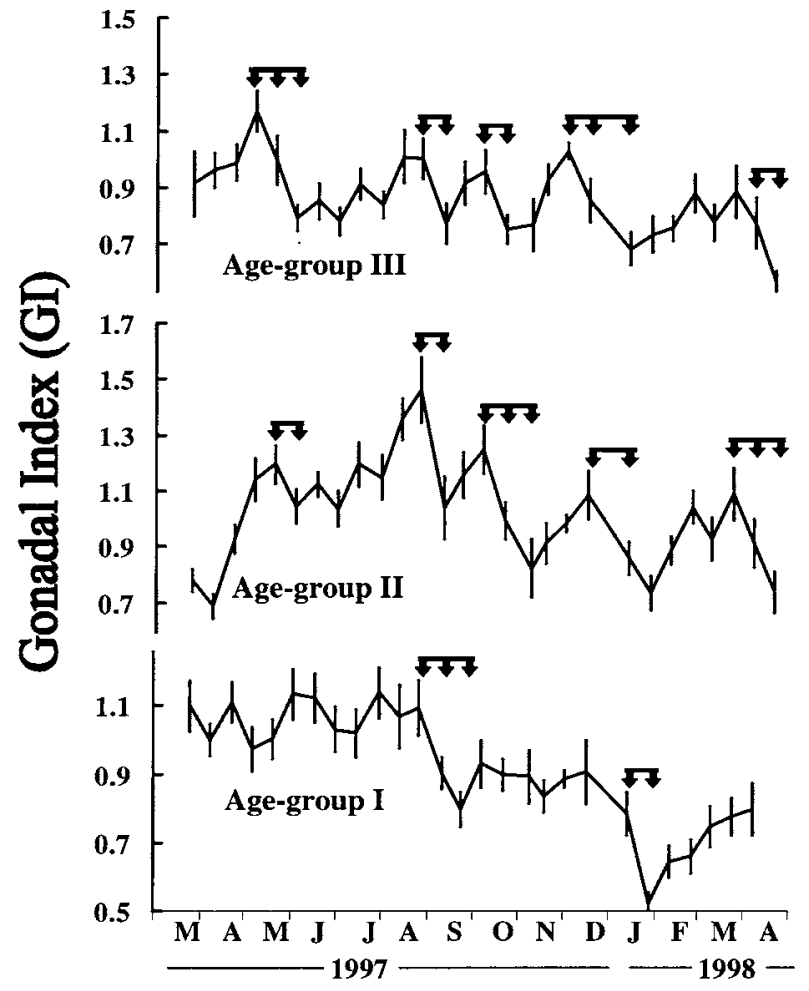

Figure 6. P. margaritifera: monthly evolution of gonad index, GI, for three age-groups. Preliminary insights into the data showed that GI evolution of males and females followed the same pattern, so that all the data were pooled. Vertical bars represent the $95 \%$ confidence intervals.

$74.4 \%, \mathrm{ER}_{2}$ (which takes into account all production) increased in the same way from 6.8 to $37.8 \%$. A general asymptotic model was proposed on the basis of these data to express $\mathrm{ER}_{2}$ in relation to the age of pearl oyster. Two a priori assumptions were made to assess the model: $\mathrm{ER}_{2}$ tends to zero in very young oysters and reaches an asymptotic value of $60 \%$ in old oysters. The asymptotic model obtained was the following (age is expressed in years): $\mathrm{ER}_{2}=60 /(1+74$ $\left.\mathrm{e}^{-1.4 \text { age }}\right)$ with $n=5, \mathrm{~F}_{\text {ratio }}=205.6, \mathrm{R}^{2}=0.99$ and $P<$ 0.05 . Since sample size is low, this model needs to be confirmed by additional measurements.

Table V. Somatic production $\left(\mathrm{P}_{\mathrm{G}}\right)$, organic shell production $\left(\mathrm{P}_{\mathrm{S}}\right)$ and reproductive outputs $\left(\mathrm{P}_{\mathrm{R}}\right)$ for the period from March 1997 to April 1998 for each age-group.

\begin{tabular}{|c|c|c|c|c|c|}
\hline & $\mathrm{P}_{\mathrm{S}}$ & $\begin{array}{c}\mathrm{P}_{\mathrm{G}} \\
\left(\mathrm{g} \cdot \mathrm{year}^{-1}\right)\end{array}$ & $P_{R}$ & $\mathrm{ER}_{1}$ & $\mathrm{ER}_{2}$ \\
\hline Age-group I & $2.04(0.27)$ & $1.20(0.18)$ & $0.24(0.09)$ & 16.5 & 6.8 \\
\hline Age-group II & $3.83(0.63)$ & $2.32(0.49)$ & $2.10(1.05)$ & 47.5 & 25.4 \\
\hline Age-group III & $3.44(0.88)$ & $0.90(0.72)$ & $2.64(1.38)$ & 74.4 & 37.8 \\
\hline
\end{tabular}

Reproductive effort was calculated on the basis of productions values obtained $\left(\mathrm{ER}_{1}=\mathrm{P}_{\mathrm{R}} /\left(\mathrm{P}_{\mathrm{G}}+\mathrm{P}_{\mathrm{R}}\right) ; \mathrm{ER}_{2}=\mathrm{P}_{\mathrm{R}} /\left(\mathrm{P}_{\mathrm{S}}+\mathrm{P}_{\mathrm{G}}+\mathrm{P}_{\mathrm{R}}\right)\right)$. The $95 \%$ confidence interval is indicated in brackets. 


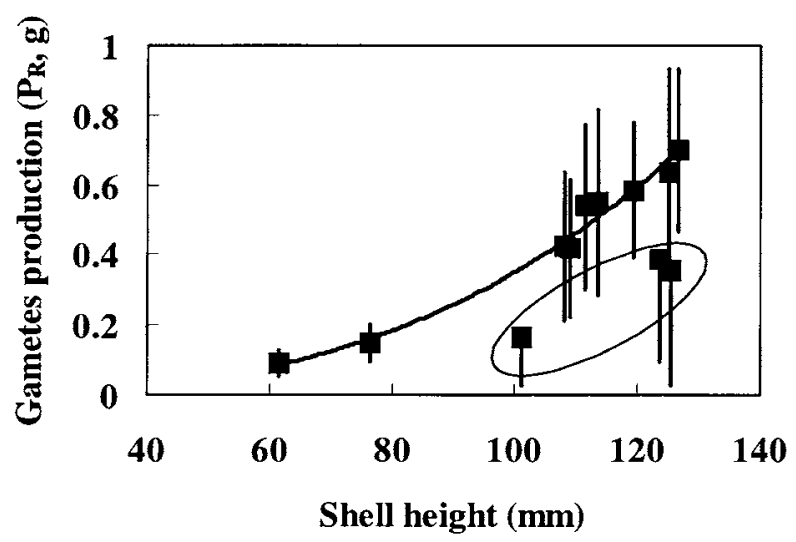

Figure 7. Relationship between gamete production $\left(\mathrm{P}_{\mathrm{R}}, \mathrm{g}\right)$ and height $(\mathrm{H}, \mathrm{mm})$ of $P$. margaritifera. Vertical bars represent confidence intervals. Encircled data correspond presumably to partial spawning events. A general model was fitted for maximal $P_{R}$ values: $P_{R}(g)=$ $5.26 \times 10^{-7} \mathrm{H}(\mathrm{mm})^{2.91}\left(\mathrm{R}^{2}=0.99, P<0.05\right)$.

\section{DISCUSSION}

\subsection{Sexuality}

The present investigations have revealed that $P$. margaritifera becomes sexually mature at the end of the first year (below $40 \mathrm{~mm}$ ), and this confirms results of earlier studies [69]. Since P. albina and P. fucata become sexually mature within the first 6 months and probably spawn twice in the first year [66, 70], $P$. margaritifera and also P. maxima [54] are, by comparison, late-maturing species, implying that smaller species ( $P$. albina and $P$. fucata) mature more rapidly than larger ones ( $P$. margaritifera and $P$. maxima).

The majority of young $P$. margaritifera in culture were mature for the first time as males, as is generally the case in pearl oysters [68-70]. Afterwards, the sex ratio of $P$. margaritifera tends increasingly towards femaleness as the population becomes older, and this phenomenon can only be explained satisfactorily on the basis of extensive protandric sex change. This finding supports those of Tranter [69] who considered $P$. margaritifera to be a protandric consecutive hermaphrodite. If, on rare occasions, male and female phases were observed simultaneously in the same specimen, they were typically separated temporally. The ability of $P$. margaritifera to change sex above a certain size appears to be typical of Pteriidae [54, 57, 69]. Tranter [69] also observed rare protogynic changes in this species and assumed that several sexual phases occur in the life of an individual. These sexual changes are known to be potentially related to food availability. As a general case, good conditions will favour femaleness, whereas bad conditions, or stress, retard it.

\subsection{Reproductive cycle}

It is apparent from the data presented herein that $P$. margaritifera in culture displayed a continuous synchronised polymodal breeding pattern throughout the year, with no 'inactive' period. In that respect, $P$. margaritifera can be classified into the 'continuous spawner' bivalve group.

Continuous breeding is common in the genus Pinctada (reviewed by Gervis and Sims [19]). Concerning histological development, such continuous reproductive competence is explained by the fact that: 1) follicles in a same gonad are not generally at the same stage; 2) gametogenesis is rapid and always active [24, 27, 75]; and 3) spawning is generally incomplete. Concerning the third point, incomplete spawning has been frequently observed in Pteriidae, with some resorption of gametes [19, 68, 70]. However, Tranter [69] found P. margaritifera emitted almost all of their gonad material. Our results tend to show that the two possibilities can occur for $P$. margaritifera in Takapoto lagoon; for example, 3-year-old pearl oysters spawned five times during our study: three spawnings were significantly higher in quantity than the other two.

This study showed that having permanently mature gonads, ready for spawning, is the reproductive strategy of P. margaritifera. This 'opportunistic strategy' consists in investment of any surplus energy into gamete production, since no physical factors are limiting for gametogenesis (see below). Surplus energy is permitted by the very high pumping capacity of $P$. margaritifera [44, 45, 76], which allows rapid growth but also continuous breeding of $P$. margaritifera, in spite of the low food concentration of Takapoto lagoon [10].

This reproductive strategy differs from those observed in temperate areas [31], where most marine bivalves have an annual reproductive cycle with welldefined periods of storage, gametogenesis, spawning and inactivity controlled by the variation of several environmental factors. However, a reproductive cycle still exists in $P$. margaritifera but concerns the intensity of the spawning. In this study, major reproductive events occurred during the warm season (DecemberApril) and this is in total agreement with other studies that have investigated reproduction in tropical bivalves [18, 20, 27, 75].

\subsection{Environmental factors}

Gamete maturation and spawning in bivalves is mainly controlled by two factors, water temperature and food supply, and secondarily, by salinity and photoperiod. In temperate waters, temperature is the major factor in the regulation of bivalve reproduction (e.g. $[38,72])$ but this environmental parameter is considered to be less effective in regulating gametogenesis in tropical populations [15, 16, 26, 27, 61]. Working on P. fucata, Wada et al. [74] concluded that tropical temperatures make the reproductive cycle less 
Table VI. Reproductive effort, calculated as $\mathrm{P}_{\mathrm{R}} /\left(\mathrm{P}_{\mathrm{R}}+\mathrm{P}_{\mathrm{G}}+\mathrm{P}_{\mathrm{S}}\right)$, in six bivalve species related to age. In all cases, reproductive effort increases with increasing age. Interspecific variability is low.

\begin{tabular}{|c|c|c|c|c|}
\hline & \multicolumn{3}{|c|}{ Reproductive effort (\%) } & \multirow{2}{*}{ References } \\
\hline & Age-group I & Age-group II & Age-group III & \\
\hline \multicolumn{5}{|l|}{ Temperate areas } \\
\hline Chlamys varia & 0 & - & 29 & {$[34]$} \\
\hline Patinopecten yessoensi & 3 & - & 38 & [17] \\
\hline Mytilus edulis & 0 & 10 & 25 & [6] \\
\hline Ostrea edulis & 0 & 18 & 30 & {$[50]$} \\
\hline Crassostrea gigas & - & 18 & - & [12] \\
\hline \multicolumn{5}{|l|}{ Tropical areas } \\
\hline Pinctada margaritifera & 7 & 25 & 38 & this study \\
\hline
\end{tabular}

distinct, and continuous spawning becomes prevalent. This is also the case in Takapoto lagoon, where the continuous reproduction of $P$. margaritifera could be explained by the fact that temperature is always above the critical level (temperature is around $28{ }^{\circ} \mathrm{C}$ and annual thermal amplitude is around $4-5^{\circ} \mathrm{C}$ ). This conclusion fits well with results of Tranter [66-70] showing that, in higher latitudes, the breeding time for pearl oysters is more restricted and occurs preferentially during warmer months, while in lower latitudes (such as Takapoto atoll) there is a less restricted spawning season and major spawning can also occur outside the warmer months. In order to really test the temperature effects, it would be of interest to investigate variation in reproductive physiology of $P$. margaritifera within various Polynesian atolls, since they exhibit graded conditions of temperature range according to their latitude.

The importance of food availability has also been emphasised in the timing of bivalve reproduction [5]. A relationship between reproductive cycle and food availability has been demonstrated by several authors (e.g. [60]), and is thought to ensure adequate nutrition for developing planktonic larvae. In Takapoto atoll, potential food for pearl oysters varies on a monthly basis, but does not present any seasonal trend $[10,46]$. The breeding cycle is presumably influenced by these monthly variations. In that respect, a deterministic model of growth and reproduction based on ecophysiological concepts and particulate organic matter (POM, potential food for pearl oysters) has now been built [47] and proposes a link between POM and gonad weight.

Two others environmental parameters are also supposed to have some effect on gonadal maturation: salinity [24, 63] and photoperiod [15, 41]. Nevertheless, in Takapoto atoll, these two parameters are nearly constant (see $[10,46]$ ), and consequently their influence on gametogenesis is probably not significant.

\subsection{Reproductive effort}

Surplus energy is shared between somatic and reproductive compartments [21]. The fraction of total growth allocated to reproduction is called the reproductive effort $[33,35,39]$. In temperate species, sur- plus energy is first stored and is afterwards transferred to reproduction at the most favourable time for larval development and recruitment success. In tropical species, this allocation is presumably continuous based on the comments above. Calculated on an annual basis to permit inter-specific comparison, reproductive effort (ER, \%) exhibited in P. margaritifera a progressive increase with age: from 6.8 to $37.8 \%$ if all production is take into account, or from 16.5 to $74.4 \%$ if shell growth is ignored. Available values for reproductive effort for bivalves are scarce in the literature. However, the review described in table VI showed that 1) inter specific variations of reproductive effort are low, and 2) differences in ER between tropical and temperate species are insignificant when calculated on an annual basis.

As a conclusion, this study confirms that, as it is the case for most of tropical bivalves, P. margaritifera has developed a continuous reproductive pattern, which differs from seasonal reproductive cycles observed in temperate species. This continuous breeding activity is permitted by the very low fluctuations of environmental parameters in Takapoto. Nevertheless, on an annual basis, the annual energy investment of $P$. margaritifera in reproduction remains approximately as expensive as those in temperate species. In spite of the low food concentration of Takapoto lagoon, this energetic cost is ensured by the high pumping capacity, previously demonstrated in this bivalve. Building a deterministic growth model for $P$. margaritifera was expected to give more insight into the relationship between somatic growth, gametogenic activity and environmental parameters (mainly food supply). This model is the scope of another paper [47].

Acknowledgements. This work was carried out at in French Polynesia at the Ifremer Pacific Oceanological Centre and was supported by the General Research Program on Pearl Oyster ('Programme Général de Recherche sur la Nacre, deuxième phase, PGRN 2'). This program was founded by the French research ministry, the French overseas ministry and the French Polynesia government. We would like to thank all the persons from the Ifremer Pearl Oyster laboratory and the SRM field station, especially S. Robert, G. Jon- 
quières, X. Caisey, A. Bennett, H. Teissier and G. Haumani for their useful help during biometry measurement. Special thanks to Professor M. Le Pennec, Dr Y.M. Paulet from the UBO university (Brest,

\section{REFERENCES}

[1] Avendaño M., Le Pennec M., Intraspecific variation in gametogenesis in two populations of the Chilean molluscan bivalve, Argopecten purpuratus (Lamarck), Aquac. Res. 28 (1997) 175-182.

[2] Bacher C., Héral M., Deslous-Paoli J.M., Razet D., Modèle énergétique uniboite de la croissance des huîtres (Crassostrea gigas) dans le bassin de Marennes-Oléron, Can. J. Fish. Aquat. Sci. 48 (1991) 391-404.

[3] Barillé L., Héral M., Barillé-Boyer A.L., Modélisation de l'écophysiologie de l'huître Crassostrea gigas dans un environnement estuarien, Aquat. Living Resour. 10 (1997) 31-48.

[4] Bayne B.L., Aspects of reproduction in bivalve molluscs, in: Wiley M. (Ed.), Estuarine Processes, Vol. I. Uses, Stresses and Adaptation to the Estuary, Academic Press, New York, 1976, pp. 432-448.

[5] Bayne B.L., Newell R.C., Physiological energetics of marine molluscs, in: Saleuddin A.S.M., Wilbur K.M. (Eds.), The Mollusca, Vol. 4, Academic Press, London, 1983, pp. 407-515.

[6] Bayne B.L., Widdows J., The physiological ecology of two populations of Mytilus edulis L, Oecologia 37 (1978) 137-162.

[7] Beninger P.G., A qualitative and quantitative study of the reproduction cycle of the giant scallop, Placopecten magellanicus, in the Bay of Fundy (New Brunswick, Canada), Can. J. Zool. 65 (1987) 495-498.

[8] Beninger P.G., Le Pennec M., Reproductive characteristics of a primitive bivalve from a deep-sea reducing environment: giant gametes and their significance in Acharax alinae (Cryptodonta: Solemyidae), Mar. Ecol. Prog. Ser. 157 (1997) 195-206.

[9] Brousseau D.J., Gametogenesis and spawning in intertidal oysters (Crassostrea virginica) from western Long Island Sound, J. Shellfish Res. 14 (1995) 483 487.

[10] Buestel D., Pouvreau S., Évolution spatio-temporelle de la matière en suspension, nourriture potentielle pour l'huître perlière Pinctada margaritifera, dans le lagon de Takapoto (Tuamotu, Polynésie Française), Oceanol. Acta 23 (2000) in press.

[11] Deslous-Paoli J.M., Héral M., Crepidulata fornicata L. (Gastéropode, Calyptraeidae) dans le bassin de Marennes-Oléron : composition et valeur énergétique des individus et des pontes, Oceanol. Acta 9 (1986) 305311.

[12] Deslous-Paoli J.M., Héral M., Biochemical composition and energy value of Crassostrea gigas (Thunberg) cultured in the bay of Marennes-Oléron, Aquat. Living Resour. 1 (1988) 239-249.

[13] Dibacco C., Robert G., Grant J., Reproductive cycle of
France) and to Dr P. Southgate from the James Cook University (Townsville, Australia) for their very helpful criticisms which have considerably improved this manuscript.

the sea scallop, Placopecten magellanicus (Gemlin, 1791), on Northeastern Georges Bank, J. Shellfish Res. 14 (1995) 59-69.

[14] Félix-Pico E.F., Ibarra-Cruz M.T., Merino-Marquez R.E., Levy-Perez V.A., Garcia-Dominguez F.A., Morames-Hernandez R., Reproductive cycle of $\mathrm{Ar}$ gopecten circularis in Magadalena Bay, Mexico, Ifremer Actes de Colloques 17 (1991) 151-155.

[15] Fournier M.L., The reproductive biology of the tropical rocky oyster Ostrea iridescens (Bivalvia: Ostreidae) on the Pacific coast of Costa Rica, Aquaculture 101 (1992) 371-378.

[16] Frenkiel L., Gros O., Moueza M., Storage tissue and reproductive strategy in Lucina pectinata (Gmelin), a tropical lucinid bivalve adapted to a reducing sulfurrich, mangrove environment, Invertebr. Rep. Dev. 31 (1997) 199-210.

[17] Fuji A., Hashizume M., Energy budget for a Japanese common scallop, Patinopecten yessoensis (Jay) in Mutsu Bay, Bull. Fac. Fish. Hokkaido Univ. 25 (1974) 7-19.

[18] Garcia-Dominguez F., Ceballos-Vazquez B.P., Quezada A.T., Spawning cycle of the pearl oyster, Pinctada mazatlanica (Hanley, 1856), (Pteriidae) at Isla Espiritu Santo, Baja California Sur, Mexico, J. Shellfish Res. 15 (1996) 297-303.

[19] Gervis M.H., Sims N.A., The biology and culture of pearl oysters (Bivalvia: Pteriidae), ICLARM Stud. Rev. 21 (1992) 1-49.

[20] Grant C.M., Creese R.G., The reproductive cycle of the tuatua Paphies subtriangulata (Wood, 1828), in New Zealand, J. Shellfish Res. 14 (1995) 287-292.

[21] Harvey M., Vincent B., Spatial and temporal variations of the reproduction cycle and energy allocation of the bivalve Macoma balthica (L.) on a tidal flat, J. Exp. Mar. Biol. Ecol. 129 (1989) 199-217.

[22] Heffernan P.B., Walker R.L., Carr J.L., Gametogenic cycles of three bivalves in Wassaw sound, Georgia: I. Mercenaria mercenaria (Linnaeus, 1758), J. Shellfish Res. 8 (1989) 51-60.

[23] Hooker S.H., Creese R.G., The reproductive biology of pipi, Paphies australis (Gmelin, 1790). I. Temporal patterns of the reproductive cycle, J. Shellfish Res. 14 (1995) 7-15.

[24] Joseph M.M., Madhyastha M.N., Annual reproductive cycle and sexuality of the oyster Crassostrea madrasensis (Preston), Aquaculture 40 (1984) 223-231.

[25] Kennedy V.S., Krantz L.B., Comparative gametogenic and spawning patterns of the oyster Crassostrea virginica (Gmelin) in central Chesapeake Bay, J. Shellfish Res. 2 (1982) 133-140.

[26] Lasiak T., The reproductive cycles of the intertidal bivalves Crassostrea cucullata (Born, 1778) and Perna 
perna (Linnaeus, 1758) from the Transkei coast, Southern Africa, Veliger 29 (1986) 226-230.

[27] Lefort Y., Clavier J., Reproduction of Annachlamys flabellata, Comptopallium radula and Mimachlamys gloriosa (Mollusca: Pectinidae) in the south-west lagoon of New Caledonia, Aquat. Living Resour. 7 (1994) 39-46.

[28] Le Pennec M., Beninger P.G., Ultrastructural characteristics of spermatogenesis in three species of deepsea hydrothermal vent mytilids, Can. J. Zool. 75 (1997) 308-316.

[29] Loosanoff V.L., Seasonal changes in the adult oysters, Ostrea virginica, of Long Island Sound, Biol. Bull. 83 (1942) 195-206.

[30] Lubet P., Reproduction des mollusques, in: Barnabé G. (Coord.), Bases biologiques de l'aquaculture, Tec et Doc Lavoisier 3, 1991, pp. 167-203.

[31] Lubet P., Mann R., Les différentes modalités de la reproduction chez les mollusques bivalves, Haliotis 16 (1987) 181-195.

[32] Lubet P., Devauchelle N., Muzellec M.L., Paulet Y.M., Faveris R., Dao J.C., Reproduction of Pecten maximus from different fisheries areas: Rade de Brest, Baie de Saint-Brieuc, Baie de Seine, Ifremer Actes de colloques 17 (1991) 157-163.

[33] Lucas A., Evaluation of reproductive effort in bivalve molluscs, Malacologia 22 (1982) 183-187.

[34] Lucas A., Bioénergetique des animaux aquatiques, Masson, Paris, 1992, 179 p.

[35] Lucas A., Calvo J., Trancart M., L'effort de reproduction dans la stratégie démographique de six bivalves de l'Atlantique, Haliotis 9 (1978) 107-116.

[36] MacDonald B.A., Thompson R.J., Influence of temperature and food availability on the ecological energetic of the giant scallop Placopecten magellanicus: II. Reproductive output and total production, Mar. Ecol. Prog. Ser. 25 (1985) 295-303.

[37] MacDonald B.A., Thompson R.J., Influence of temperature and food availability on the ecological energetic of the giant scallop Placopecten magellanicus: III. Physiological ecology, the gametogenic cycle and scope for growth, Mar. Biol. 93 (1986) 37-48.

[38] Mann R., Some biochemical and physiological aspects of growth and gametogenesis in Crassostrea gigas and Ostrea edulis grown at sustained elevated temperatures, J. Mar. Biol. Assoc. UK 59 (1979) 95-110.

[39] Navarro E., Iglesias J.I.P., Energetic of reproduction related to environmental variability in bivalve molluscs, Haliotis 24 (1995) 43-55.

[40] Navarro E., Iglesias J.I.P., Larrañaga A., Interannual variation in the reproductive cycle and biochemical composition of the cockle Cerastoderma edule from Mundaca Estuary (Biscay, North Spain), Mar. Biol. 101 (1989) 503-511.

[41] Paulet Y.M., Boucher J., Is reproduction mainly regulated by temperature or photoperiod in Pecten maximus?, Invert. Reprod. Dev. 19 (1991) 61-70.

[42] Paulet Y.M., Lucas A., Gérard A., Reproduction and Aquat. Living Resour. 13 (1) (2000) larval development in two Pecten maximus (L.) populations from Brittany, J. Exp. Mar. Biol. Ecol. 119 (1988) 145-156.

[43] Pipe R.K., Seasonal cycles in and effects of starvation on egg development in Mytilus edulis, Mar. Ecol. Prog. Ser. 24 (1985) 212-128.

[44] Pouvreau S., Jonquières G., Buestel D., Filtration by the pearl oyster, Pinctada margaritifera, under conditions of low seston load and small particle size in tropical lagoon habitat, Aquaculture 176 (1999) 295 314.

[45] Pouvreau S., Bodoy A., Buestel D., In situ suspension feeding behaviour of the pearl oyster, Pinctada margaritifera: Combined effects of body size and weatherrelated seston composition, Aquaculture 181 (2000) 91-113.

[46] Pouvreau S., Tiapari J., Gangnery A., Lagarde F., Garnier M., Teissier H., Haumani G., Buestel D., Bodoy A., Growth of the Black-Lip pearl oyster, Pinctada margaritifera, in suspended culture under hydrobiological conditions of Takapoto Lagoon (French Polynesia), Aquaculture 184 (2000) 133-154.

[47] Pouvreau S., Bacher C., Héral M., Ecophysiological model of growth and reproduction of the black pearl oyster, Pinctada margaritifera, in the planktonic food web of Takapoto lagoon (French Polynesia), Aquaculture (2000) in press.

[48] Raillard O., Deslous-Paoli J.M., Héral M., Razet D., Modélisation du comportement nutritionnel et de la croissance de l'huître japonaise, Crassostrea gigas, Oceanol. Acta 16 (1993) 73-82.

[49] Robert R., Trut G., Laborde J.L., Growth reproduction and gross biochemical composition of the Manila clam Ruditapes philippinarum in the Bay of Arcachon France, Mar. Biol. 116 (1993) 291-299.

[50] Rodhouse P.G., Energy transformations by the oyster Ostrea edulis L. in a temperate estuary, J. Exp. Mar. Biol. Ecol. 34 (1978) 1-22.

[51] Rodhouse P.G., Roden C.M., Burnell G.M., Hensey M.P., McMahon T., Ottway B., Ryan T.H., Food resource, gametogenesis and growth of Mytilus edulis on the shore and in suspended culture: Killary Harbour, Ireland, Mar. Biol. 64 (1984) 513-529.

[52] Rodriguez-Moscoso E., Arnaiz R., Gametogenesis and energy storage in a population of the grooved carpetshell clam, Tapes decussatus (Linné, 1787), in northwest Spain, Aquaculture 162 (1998) 125-139.

[53] Roman G., Acosta C.P., Reproductive and reserve storage cycles in Pecten maximus reared in suspension: I. Soft tissue growth and reproduction, Ifremer Actes de colloques 17 (1995) 183-187.

[54] Rose R.A., Dybdahl R.E., Harders S., Reproductive cycle of the western australian silverlip pearl oyster, Pinctada maxima (Jameson) (Mollusca: Pteridae), J. Shellfish Res. 9 (1990) 261-272.

[55] Ross A.H., Nibet R.M., Dynamic models of growth and reproduction of the mussel Mytilus edulis L., Funct. Ecol. 4 (1990) 777-787.

[56] Sastry A.N., Pelecypoda (excluding Ostreidae), in: Giese A.C., Pearse J.S. (Eds.), Reproduction of Marine 
Invertebrates, Vol. 5, Academic Press, New York, 1979, pp. 113-292.

[57] Saucedo P., Monteforte M., In situ growth of pearl oysters Pinctada mazatlanica (Hanley 1856) and Pteria sterna (Gould 1851) under repopulation conditions at Bahia de La Paz, Baja California Sur, Mexico, Aquac. Res. 28 (1997) 367-378.

[58] Schneider D.W., A bioenergetics model of zebra mussel, Dreissena polymorpha, growth in the great lakes, Can. J. Fish. Aquat. Sci. 49 (1992) 1406-1416.

[59] Seed R., The ecology of Mytilus edulis L. (Lamellibranchiata) on exposed rocky shores. 1. Breeding and settlement, Oecologia 3 (1969) 277-316.

[60] Shafee M.S., Reproduction of Perna picta (Mollusca: bivalvia) from the Atlantic coast of Morocco, Mar. Ecol. Prog. Ser. 53 (1989) 235-245.

[61] Shpigel M., Gametogenesis of the European Flat Oyster (Ostrea edulis) and Pacific Oyster (Crassostrea gigas) in warm water in Israel, Aquaculture 80 (1989) 343-349.

[62] Sournia A., Ricard M., Données sur l'hydrologie et la productivité du lagon d'un atoll fermé (Takapoto, Iles Tuamotu), Vie Milieu 26 (1976) 243-279.

[63] Stephen D., The reproductive biology of the Indian oyster Crassostrea madrasensis (Preston), gametogenic cycle and biochemical levels, Aquaculture 21 (1980) 147-153.

[64] Taylor A.C., Venn T.J., Seasonal variation in weight and biochemical composition of the tissues of the queen scallop, Chlamys opercularis, from the Clyde sea area, Mar. Biol. 59 (1979) 605-621.

[65] Thielley M., Weppe M., Herbault C., Ultrastructural study of gametogenesis in the French Polynesian black pearl oyster Pinctada margaritifera (Mollusca, Bivalvia), I- spermatogenesis, J. Shellfish Res. 12 (1993) 41-47.

[66] Tranter D.J., Reproduction in Australian pearl oysters (Lamellibranchia). I. Pinctada albina (Lamarck): primary gonad development, Aust. J. Mar. Freshwater Res. 9 (1958) 135-143.

[67] Tranter D.J., Reproduction in Australian pearl oysters
(Lamellibranchia). II. Pinctada albina (Lamarck): gametogenesis, Aust. J. Mar. Freshwater Res. 9 (1958) $144-158$.

[68] Tranter D.J., Reproduction in Australian pearl oysters (Lamellibranchia). III. Pinctada albina (Lamarck): Breeding season and sexuality, Aust. J. Mar. Freshwater Res. 9 (1958) 191-216.

[69] Tranter D.J., Reproduction in Australian pearl oysters (Lamellibranchia). IV. Pinctada margaritifera (Linnaeus), Aust. J. Mar. Freshwater Res. 9 (1958) 511-525.

[70] Tranter D.J., Reproduction in Australian pearl oysters (Lamellibranchia). V. Pinctada fucata (Gould), Aust. J. Mar. Freshwater Res. 10 (1959) 45-66.

[71] VanHaren R.J.F., Kooijman S.A.L.M., Application of a dynamic energy budget model to Mytilus edulis (L.), Neth. J. Sea Res. 31 (1993) 119-133.

[72] Velez A., Epifanio C.E., Effects of temperature and ration on gametogenesis and growth in the tropical mussel Perna perna (L.), Aquaculture 22 (1981) 2126.

[73] Villalba A., Gametogenic cycle of cultured mussel, Mytilus galloprovincialis, in the bays of Galicia (N. W. Spain), Aquaculture 130 (1995) 269-277.

[74] Wada K.T., Komaru A., Ichimura Y., Kurosaki H., Spawning peak occurs during winter in the Japanese subtropical population of the pearl oyster, Pinctada fucata fucata (Gould, 1850), Aquaculture 133 (1995) 207-214.

[75] Wolff M., Spawning and recruitment in the Peruvian scallop Argopecten purpuratus, Mar. Ecol. Prog. Ser. 42 (1988) 213-217.

[76] Yukihira H., Klumpp D.W., Lucas J.S., Effects of body size on suspension feeding and energy budgets of the pearl oysters Pinctada margaritifera and P. maxima, Mar. Ecol. Prog. Ser. 170 (1998) 119-130.

[77] Zwarts L., Seasonal variation in body weight of the bivalves Macoma balthica, Scrobicularia plana, Mya arenaria and Cerastoderma edule in the Dutch Wadden sea, Neth. J. Sea Res. 28 (1991) 231-245. 